\title{
Studi Analisis Metode Hisab Awal Waktu Salat Ahmad Ghozali dalam "Irsyad al-Murid"
}

\author{
Nashifatul Wadzifah \\ dzifany27@yahoo.com
}

\begin{abstract}
Abstrak
Salat merupakan salah satu kewajiban yang harus dilaksanakan oleh umat Islam pada waktu yang telah ditentukan. Al-Qur'an tidak menyebutkan secara rinci tentang kapan waktu unuk melaksanakan salat fardlu. Hadis Rasulullah yang merupakan tabyin bagi ayat-ayat al-Qur'an, telah menjelaskan waktu salat yaitu dengan melihat tanda-tanda yang ditunjukkan oleh alam. Untuk melihat (rukyah) tanda-tanda tersebut tidak semudah yang dipaparkan oleh teori sehingga dengan berkembangnya khazanah keilmuan seperti ilmu falak sangat dibutuhkan untuk membantu dan memudahkan umat Islam untuk mengetahui masuknya awal waktu salat yang sesuai perintah al-Qur' an dan Hadis tersebut dengan menggunakan hisab.

Kitab Irsyâd al-Murîd ilâ Ma'rifati 'Ilmi al-Falak 'alâ al-Rashdi al-Jadîd (Panduan bagi Murid tentang Ilmu Falak dalam Tinjauan Baru) yang selanjutnya penulis sebut Irsyâd al-Murîd, karangan Ahmad Ghozali ini merupakan kitab yang dikategorikan ke dalam hisab kontemporer. Pada kitab ini juga memuat hisab awal waktu salat, namun dalam kitab ini metode hisab awal waktu salatnya menggunakan konsep yang berbeda. Perbedaan tersebut terletak pada data Matahari yang digunakan dan koreksi terbit terbenam yang lebih kompleks. Adanya perbedaan tersebut apakah hasil hisab dalam kitab tersebut akurat jika dibandingkan dengan sistem Ephemeris yang digunakan pada era sekarang ini dan layak dijadikan panduan untuk beribadah? Kata Kunci: Waktu Salat, Irsyâd al-Murîd, Akurat.
\end{abstract}

\section{A. Prolog}

Salat merupakan rukun Islam kedua setelah sahadat, juga merupakan perintah langsung dari Allah Swt yang diberikan kepada Nabi Muhammad Saw ketika melaksanakan misi suci Isra' Mi'raj yang terjadi pada tanggal 27 Rajab tahun 12 setelah kenabian. ${ }^{1}$ Menentukan waktu salat merupakan persoalan fundamental dan signifikan ketika dihubungkan dengan sah tidaknya salat. Hal ini dikarenakan dalam menunaikan kewajiban salat tersebut, kaum muslimin terikat pada waktu-waktu yang sudah ditentukan. ${ }^{2}$ Sebagaimana tercantum dalam surat al-Nisa' ayat 103 :

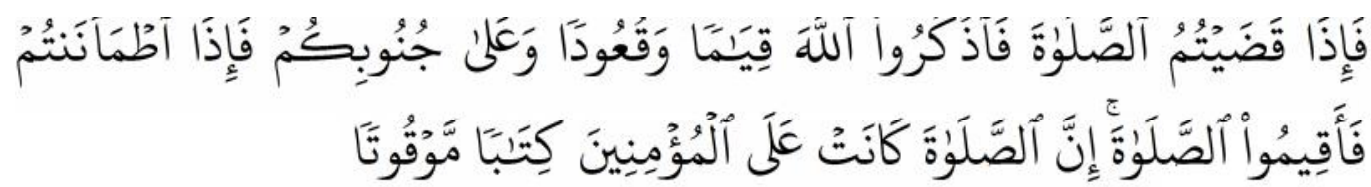

\footnotetext{
${ }^{1}$ Slamet Hambali, Ilmu Falak 1, Semarang: Program Pascasarjana IAIN Walisongo, 2012, hlm. 103.

${ }^{2}$ Susiknan Azhari, Ilmu Falak Perjumpaan Khazanah Islam dan Sains Modern, Yogyakarta: Suara Muhammadiyah, Cet.II, 2007, hlm. 63.
} 
Artinya: "Sesungguhnya salat itu adalah kewajiban yang ditentukan waktu-waktunya atas orang-orang yang beriman". (al- Nisa':103) ${ }^{3}$

Ayat di atas hanya menyatakan bahwa salat adalah kewajiban yang telah ditentukan waktunya, tetapi pada ayat di atas tidak disebutkan kapan waktu pelaksanaannya dan berapa jumlah waktu salat tersebut.

Para ulama fiqh kemudian memberikan batasan-batasan waktu salat dengan berbagai cara atau metode yang mereka asumsikan untuk menentukan waktu-waktu salat tersebut. Salat lima waktu tersebut adalah:

\section{Waktu Zuhur}

Waktu Zuhur dimulai sesaat setelah Matahari terlepas dari titik kulminasi atas, atau saat Matahari tergelincir. Mengenai akhir waktu salat Zuhur adalah sampai panjang bayangbayang suatu benda mempunyai panjang yang sama dengan benda tersebut. ${ }^{4}$

\section{Waktu Asar}

Waktu Asar dimulai saat bayang-bayang suatu benda sama dengan panjang benda tersebut, sampai tiba waktu Maghrib. Hal ini dilakukan Nabi ketika Matahari berkulminasi dan benda tidak memiliki bayangbayang. Nabi juga melakukan salat Asar pada saat panjang bayang-bayang dua kali panjang dirinya. Hal ini terjadi ketika Matahari pada saat kulminasi, dan panjang bayang-bayang suatu benda sama dengan benda tersebut. ${ }^{5}$

\section{Waktu Maghrib}

Waktu salat Maghrib dimulai sejak Matahari terbenam sampai terbenam syafaq (mega merah). ${ }^{6}$

4. Waktu Isya

Waktu Isya dimulai sejak hilangnya mega merah sampai separuh malam, dan akhir salat Isya adalah terbitnya fajar. ${ }^{7}$

\section{Waktu Subuh}

Waktu salat Subuh yang utama adalah dari terbit fajar sadiq, yakni fajar kedua sampai berakhirnya gelap malam karena Nabi SAW biasa mengerjakannya pada waktu gelap malam masih pekat. Waktu diperbolehkannya salat Subuh berakhir sampai terbit Matahari. ${ }^{8}$

Ketentuan waktu salat yang diterangkan atau ditunjukkan oleh Rasulullah Saw baru sebatas fenomena alam, tidak ada spesifikasi kapan waktunya. Secara otomatis fenomena alam seperti ini akan memunculkan persoalan bagi kita, pada saat langit mendung dan Matahari tidak memantulkan sinarnya, maka kita akan kesulitan dalam mendeteksi posisi Matahari untuk dijadikan dasar penentuan awal dan akhir waktu salat.

${ }^{3}$ Departemen Agama Republik Indonesia, al-Quran Dan Terjemahnya, Jakarta: Bumi Restu, 1974, hlm. 125.

${ }^{4}$ Ahmad Izzuddin, Ilmu Falak Praktis (Metode Hisab-Ru'yah dan Solusi Permasalahannya), Semarang: Komala Grafika, 2006, hlm.56.

${ }_{5}^{5}$ Ibid, hlm. 56-57.

${ }^{6}$ Syafaq adalah warna merah yang berada pada tempat terbenamnya Matahari. Apabila warna merahnya telah lenyap dan tidak kehilangan sedikipun. Lihat, Imam Syafi'i Abu Abdullah Muhammad bin Idris, Mukhtashar Kitab Al-Umm fiil Fiqhi, Mohammad Yasir Abd Muthalib, “Ringkasan Kitab Al Umm”,Jakarta: Pustaka Azzam, 2004, hlm.114.

${ }^{7}$ Lihat Imam Taqiyuddin Abi Bakar Muhammad Husain, Kifayah al-Akhyar Fi Halli Gayatul Ikhtisar, Juz. I, Surabaya: Dar al-Kitab al-Islam, hlm. 84.

${ }^{8}$ Sa'id bin Ali bin Wahf al-Qohtani, Ensiklopedi Salat menurut al-Qur'an dan Sunnah, JATCC: Pustaka Imam Al-Syafi'i, 2008, hlm. 247. 
Adanya persoalan ini, untuk membantu merealisasikan perintah tentang batasan awal waktu salat dalam teks al-Qur'an dan hadis diatas perlu sebuah rumusan dalam menentukan awal waktu salat. Artinya perlu konsep kejelasan waktu yang tepat. Dalam hal ini lebih kongkritnya penulis sebut dengan kejelasan jam. Artinya sebagai patokan waktu, pada jam-jam berapa mulai awal waktu salat itu.

Untuk menentukan waktu-waktu salat sesuai gambaran Al-Qur'an dan hadis Nabi, para ulama berbeda dalam metode dan cara mentukan waktu salat, timbul dua aliran yaitu aliran klasik dan modern. Aliran klasik dalam merumuskan metode atau cara penentuan waktu-waktu salat lebih kepada fenomena alam yang sesuai dengan teks hadis di atas. Dalam menentukan waktu-waktu salat aliran ini menggunakan bantuan alat yaitu tongkat istiwa ${ }^{9}$ atau sundial ${ }^{10}$. Menurut aliran ini setiap kali ingin melakukan salat, maka harus keluar untuk melihat tongkat atau keadaan langit. Cara seperti ini memang cukup mudah dan sederhana, akan tetapi hal ini akan menemukan kesulitan ketika langit mendung ataupun keadaan hari sedang hujan. Inilah salah satu kesulitan metode rukyah dalam menentukan waktu salat.

Sedangkan aliran modern dalam merumuskan metode atau cara penentuan waktu-waktu salat, mereka memahami bahwasanya dalam menentukan waktu salat bisa dengan mengunakan hisab. ${ }^{11}$ Ahmad Izzuddin ${ }^{12}$ menamakan kedua aliran ini sebagai mazhab Rukyah untuk aliran klasik, dan mazhab Hisab untuk aliran modern.

Seiringdengan perkembangannya dibandingkan dengan wacana hisab rukyah yang lain. Sebagaimana halnya penentuan awal bulan kamariah, penentuan waktu salat ternyata tidak menuai perdebatan. Walaupun timbul dua mazhab yang berbeda yaitu mazhab Rukyah dan mazhab Hisab. Kedua mazhab ini saling membutuhkan antara satu sama lainnya, sehingga ketika metode rukyah mengalami kesulitan atau bermasalah maka metode hisab yang digunakan. Seperti yang diungkapkan oleh Ahmad Izzuddin:

Dikotomi Mazhab Hisab dan Mazhab Rukyah dalam persoalan penentuan waktu salat, tidak menampakkan adanya suatu persoalan yang "greget besar". Bahkan sekat pemisah mazhab-mazhab tersebut tampak tidak muncul (tidak ada). Karena menurut hemat penulis, dalam persoalan penentuan waktu salat ini, oleh masyarakat kedua mazhab tersebut sudah diakui validitas dan keakuratan hasilnya. Hal ini tampak jelas dari fenomena diatas, dimana dapat ditemukan jadwal waktu salat di setiap masjid yang di depannya juga dipasang bencet dan tongkat istiwa. Hal ini bisa dimaklumi, karena hasil hisab sudah terbukti keakuratanya dan validitasnya (sesuai dengan hasil rukyah). Sehingga dalam hal ini, baik bagi Mazhab Hisab maupun Mazhab Rukyah telah berlaku apa yang disebut dengan simbiosis mutualisme, di mana apa yang dilakukan oleh Mazhab Rukyah bisa dipakai sebagai bukti empirik dari hasil Mazhab Hisab, begitu pula sebaliknya. ${ }^{13}$

${ }^{9}$ Dalam bahasa Jawa dikenal dengan sebutan bencet, yaitu sebuah alat sederhana yang terbuat dari semen atau semacamnya yang diletakan di tempat tebuka agar mendapat sinar Matahari. Alat ini berguna untuk mengethaui waktu Matahari hakiki, yang dipakai untuk menentukan waktu salat , tanggal Syamsiyah, serta untuk mengetahui pranotomongso. Lihat Muhyiddin Khazin, Kamus Ilmu Falak, Buana Pustaka: Yogyakarta, 2005, hlm. 12.

10 Jam Matahari dalam bahasa Arab disebut al-Sa'ah al-Syamsiah atau Mizwala. Lihat Susiknan Azhari, Ensiklopedi Hisab Rukyah, Pustaka Pelajar: Yogyakarta, 2005, cet I, hlm: 144

${ }^{11}$ Dimana hakikat hisab waktu salat adalah menghitung kapan Matahari akan menempati posisi-posisi seperti tersebut dalam nash-nash waktu salat itu.

${ }^{12}$ Ahmad Izzuddin, loc.cit, hlm. 38. Lihat juga Ahmad Izzuddin, Ilmu Falak Praktis (Metode Hisab Rukyah Praktis Soluusi dan Permasalahannya), Semarang: Komala Grafika, 2006, hlm. 52.

${ }^{13}$ Ibid, hlm. 39. 
Pada zaman modern seperti sekarang ini, di mana kebutuhan manusia lebih condong pada hal yang praktis, termasuk juga masalah waktu salat, manusia tidak mau susah melihat langit ketika ingin melaksanakan salat. Keadaan seperti ini, maka metode hisab dapat dijadikan sebagai acuan utama dalam menentukan waktu salat yang masih perlu dilakukan evaluasi secara terus-menerus dalam perkembangannya. Perkembangan ilmu falak di Indonesia, sistem hisab dapat digolongkan menjadi beberapa generasi: ${ }^{14}$

1. Hisab Hakiki Takribi. Termasuk dalam generasi ini kitab Sullam al- Nayyirain karya Mansur bin Abdul Hamid bin Muhammad Damiri el- Betawi dan Kitab Fathu al-Rauf al-Mannan karya Abu Hamdan Abdul Jalil.

2. Hisab Hakiki Tahkiki. Termasuk dalam kelompok ini, seperti kitab al- Khulâshat al-Wafiyah karya KH. Zubaer Umar al-Jaelani Salatiga, kitab Badi'ah al-Mitsal karya K.H Ma'shum Jombang, dan Hisab Hakiki karya KRT Wardan Diponingrat. ${ }^{15}$

3. Hisab Hakiki Kontemporer. Termasuk dalam generasi ketiga ini, seperti The New Comb, Ephemeris ${ }^{16}$, Astronomical Almanac, ${ }^{17}$ Islamic Calendar karya Muhammad Ilyas, Mawaqit karya Dr. Ing. Khafid ${ }^{18}$, dan Irsyâd al-Murîd ilaa Ma'rifati 'Ilmi al-Falak 'alâ al-Rashdi al-Jadîd.

Irsyâd al-Murîd ilaa Ma'rifati 'Ilmi al-Falak 'alâ al-Rashdi al- Jadîd (Panduan bagi Murid tentang Ilmu Falak dalam Tinjauan Baru), yang selanjutnya penulis sebut dengan Irsyâd al-Murîd, adalah salah satu karya dari KH. Ahmad Ghozali seorang tokoh falak dari Madura, dia menjabat sebagai Penasehat LFNU Jatim, anggota BHR Jatim, anggota Hisab dan Rukyah Kementrian Agama RI. Kitab ini merupakan kitab yang dikategorikan kedalam hisab kontemporer. Sebab sebuah sistem atau metode hisab dapat dikategorikan kedalam hisab kontemporer jika memenuhi beberapa indikasi sebagai berikut : ${ }^{19}$

1. Perhitungan dilakukan dengan sangat cermat dan banyak proses yang harus dilalui

${ }^{14}$ Muhyidin Khazin, Kamus Ilmu Falak, cet I, Yogyakarta: Buana Pustaka, 2005, hal. 4

${ }^{15}$ Muhammad Wardan adalah tokoh muslim Indonesia yang oleh banyak kalangan disebutsebut sebagai penggagas awal munculnya konsep wujudul hilal. Lihat dalam Susiknan Azhari, Hisab \& Rukyah “Wacana Untuk Membangun Kebersamaan di Tengah Perbedaan”, Yogyakarta: Pustaka Pelajar, 2007, hal. 5.

${ }^{16}$ Dinamakan Ephemeris karena data yang dipergunakan diambil dalam buku atau almanak yang judulnya Ephemeris Hisab Rukyah. Yang diterbitkan oleh Direktorat Urusan Agama Islam dan Pembinaan Syari'ah Ditjen Bimbingan Masyarakat Islam Departemen Agama, yang pada awalnya bernama Direktorat Pembinaan Badan Peradilan Agama Islam Departemen Agama. Di dalam buku ini memuat data yang berkaitan dengan perhitungan awal bulan kamariah, awal waktu salat dan juga perhitungan arah kiblat. Data yang terdapat di dalam buku ini meliputi data

Bulan dan data Matahari yang disajikan berdasarkan waktu Greenwich Mean Time (GMT). Lihat Drs. A. Jamil, Ilmu Falak (Teori dan Praktek), Amzah: Jakarta, 2009, hlm. 67.

${ }^{17}$ Astronomical Almanac (Nautical Almanac) adalah sejenis buku yang memuat daftar posisi Matahari, Bulan, planit dan bintang-bintang penting pada saat-saat tertentu tiap hari dan malam sepanjang tahun. Maksudnya ialah mempermudah posisi-posisi kapal. Dalam buku tersebut dimua pula, pukul berapa G.M.T benda-benda langit itu mencapai Kulminasi atas, bagi setiap meridian bumi. Deklinasi dan Ascension Recta benda-benda langit, perata waktu, koreksi sextant kearena pembiasan sinar dank arena pengukuran kehorizon kodrat itu dimuat pula. Lihat P. Simamora, Ilmu Falak (Kosmografi) “Teori, Perhitungan, Keterangan, dan Lukisan”, cet XXX (Jakarta: C.V Pedjuang Bangsa, 1985), hal. 66.

${ }^{18} \mathrm{Dr}$. Ing. Khafidz adalah seorang ahli geodesi yang sekarang aktif di BAKOSURTANAL (Badan Koordinasi Survei dan Pemetaan Nasional).

${ }^{19}$ Disampaikan pada Pendidikan dan Pelatihan Hisab Rukyat Nasional Pondok Pesantren seIndonesia anggaran 2007 yang diselenggarakan oleh P.D. Pontren Kemenag RI di Masjid Agung Jawa Tengah. Lihat Kitri Sulastri, Skripsi, Studi Analisis Hisab Awal Bulan Kamariah dalam Kitab Irsyâd al-Murîd, Semarang: IAIN Walisongo, 2010, hal.10. 
2. Rumus-rumus yang digunakan lebih banyak menggunakan rumus segitiga bola

3. Data yang digunakan merupakan hasil penelitian terakhir dan menggunakan matematika yang telah dikembangkan

4. Sistem koreksi lebih teliti dan kompleks

Ahmad Ghozali mengungkapkan bahwa penyusunan kitab Irsyâd al-Murîd berdasarkan keinginannya untuk ikut memasyarakatkan ilmu Falak di kalangan umat Islam pada umumnya dan para santri pada khususnya. Oleh karena itu, kitab Irsyâd al-Murîd disusun dengan bahasa yang sederhana dan singkat sehingga mudah dipahami serta dapat dikerjakan dengan alat hitung modern. ${ }^{20}$

Dalam penentuan awal waktu salat, Irsyâd al-Murîd menggunakan rumusan konsep yang berbeda. Perbedaan ini terletak pada data deklinasi dan equation of time yang digunakan dalam perhitungan telah disediakan dan dihitung sendiri, sedangkan pada metode hisab awal waktu salat. modern yang lainnya data yang digunakan diambil dari data Ephemeris atau win hisab. Perbedaan yang lainnya ada pada konsep hisab kedudukan atau tinggi Matahari pada saat terbit dan terbenam memperhitungkan koreksi horizontal parallax 22 Matahari, sedangkan dalam metode hisab lainnya horizontal parallax ada yang tidak memperhitungkannya.

\section{B. Biografi Ahmad Ghozali}

Nama lengkap pengarang kitab Irsyâd al-Murîd, adalah Ahmad Ghozali bin Muhammad bin Fathullah bin Sa'idah al-Samfani al-Maduri yang selanjutnya penulis sebut Ahmad Ghozali, dia dilahirkan pada tanggal 7 Januari 1962 M di sebuah kampung bernama Lanbulan desa Baturasang Kec. Tambelangan Kab. Sampang, Jawa Timur. ${ }^{21}$

Ahmad Ghozali merupakan salah satu putra dari pasangan Muhammad Fathullah dan Zainab Khoiruddin. Ayahnya, Syaikhina allamah Syaikh Muhammad Fathulah adalah Muassis (perintis pertama) berdirinya Pondok Pesantren al-Mubarok Lanbulan. Pondok Pesantren Al-Mubarok Lanbulan yang terletak di daerah Pulau Garam desa Baturasang, Sampang, Madura perbatasan Bangkalan dan Sampang, Lanbulan diambil dari kata bulan nisbat dari mimpi Muhammad Fathullah yang bermimpi di Desa Baturasang Tambelangan ada Bulan jatuh bersinar di sekitar desa tersebut setelah dihampiri maka di sana (tempat jatuhnya Bulan) ada guru dia dan berkata : "Dirikanlah pesantren di sini dan berilah nama Lanbulan. Dengan hati tulus dan penuh takdim, maka didirikanlah Pondok Pesantren Lanbulan". ${ }^{22}$

Ahmad Ghozali mempunyai istri bernama Asma binti Abdul Karim pada tahun 1990 M. Dia dikaruniai sembilan orang anak (5 putra dan 4 putri), diantaranya Nurul Bashiroh, Afiyah, Aly, Yahya, Salman, Muhammad, Kholil, A'isyah, dan Sofiyah. ${ }^{23}$

\footnotetext{
${ }^{20}$ Ibid.

${ }^{21}$ Hasil wawancara dengan Ahmad Ghozali penulis kitab Irsyâd al-Murîd melalui e-mail alamat emailnya lafalalmubarok@gmail.com pada tanggal 4 Mei 2013. Lihat juga Kitri Sulastri, "Studi Analisis Hisab Awal Bulan Kamariah dalam Kitab Irsyâd al-Murîd", Semarang: IAIN Walisongo, 2010, hlm. 44.

${ }^{22}$ Ibid.

${ }^{23}$ Kitri Sulastri, "Studi Analisis Hisab Awal Bulan Kamariah dalam Kitab Irsyâd al-Murîd", Semarang: IAIN Walisongo, 2010, hlm. 44.
} 
Sejak kecil Ahmad Ghozali dididik oleh orangtuanya dengan ilmu agama, sehingga dia memiliki minat yang tinggi dalam memperdalam ilmu agama, juga selalu tekun belajar. Walaupun dia pernah mengenyam pendidikan formal hingga kelas 3 $\mathrm{SD}$, tapi dia tetap melanjutkan pendidikan agamanya di Pondok Pesantren al-Mubarok Lanbulan yang diasuh oleh ayahnya sendiri. Dia menjadi santri yang taat dan patuh, dia berguru kepada Muhammad Fathullah, selaku pengasuh Pondok Pesantren alMubarok yang juga merupakan ayahanda dari Ahmad Ghazali. Dia juga pernah berguru kepada kedua kakaknya, Kurdi Muhammad (alm) dan Barizi Muhammad. ${ }^{24}$

Tidak mudah menjadi orang alim, sukses, dan terkenal. Semuanya membutuhkan kegigihan, semangat yang tinggi dan ketekunan dalam belajar, itulah yang dilakukan oleh Ahmad Ghozali dalam menuntut ilmu.

Pada tahun 1977 Ahmad Ghozali berguru kepada Maimun Zubair Sarang, Rembang selama bulan Ramadhan, hal tersebut dilakukan setiap tahun selama 3 tahun berturut-turut sampai tahun 1980. Selain itu, dia juga menyempatkan diri untuk berguru kepada Hasan Iraqi (alm) di Kota Sampang setiap Hari Selasa dan Sabtu, pada tahun $1981 \mathrm{M}^{25}$

Pada waktu pengembaraannya menuntut ilmu, setelah mengenyam pendidikan di pondoknya sendiri, dia melanjutkan pendidikannya ke Makkah al-Mukarromah kurang lebih selama 15 tahun tepatnya di Pondok Pesantren al-Shulatiyah. Di sana dia belajar pada para ulama yang otoritas keilmuannya tidak diragukan lagi seperti Syaikh Isma'il Ustman Zain al-Yamany Al-Makky ${ }^{26}$, Syaikh Abdullah al-Lahjy, Syaikh Yasin bin Isa al-Fadany dan ulama-ulama lainnya.

Ahmad Ghozali belajar ilmu falak kepada para guru besar, seperti Syekh Mukhtaruddin al-Flimbani (alm) di Mekkah, Nasir Syuja'i (alm) di Prajjen Sampang, Kamil Hayyan (alm), Hasan Basri Sa'id (alm), kemudian pada Zubair Bungah Gresik. $^{27}$

Dia menjadi Pengasuh Pondok Pesantren al-Mubarok Lanbulan. Sedangkan dalam organisasi beliau pernah menjabat sebagai Wakil Ketua Syuriyah NU di Kab. Sampang, Ketua Syuriyah NU di Kec. Tambelangan. Penasehat LFNU Jatim, Anggota BHR Jatim. ${ }^{28}$

Begitu banyak pengalaman Ahmad Ghozai dalam hal menimba ilmu, terutama ilmu falak, sehingga dia berusaha agar ilmunya bermanfaat bagi umat Islam dengan memberikan sumbangan dengan produktif mengajar dan mengarang karya tulis berupa kitab-kitab. Namun kebanyakan dari kitabnya (khususnya kitab falak) hanya dicetak untuk kalangan sendiri, yaitu untuk materi pembelajaran di Pondok Pesantren al-Mubarok Lanbulan, Baturasang, Sampang, Madura.

\section{Karya-karya Ahmad Ghozali}

\section{${ }^{24}$ Ibid.}

${ }^{25}$ Ibid.

${ }^{26}$ Syekh Ismail al-Yamani, termasuk salah satu ulama yang Alim sekaligus Allamah pada zamannya. Kemasyhuran dan kebesaran beliau di mata para ulama begitu tinggi dan terkenal sampai ke Mesir, Yaman, Malaysia, Brunei Darussalam dan Indonesia, sehingga tak ayal lagi kalau banyak santri dan murid beliau menjadi ulama besar, sebagai penerus perjuangannya yang tidak lain hanya untuk Izzil Islam wal muslimin. Salah satu muridnya yaitu Syekh Ahmad Ghozali, Syekh Ahmad Kurdi dan Syekh Ahmad Barizi dari Sampang. diakses dari http://khoirunnada.blogspot.com/2011/01/biografisyekh-ismail-utsman-zein-al.html, pada hari Selasa tanggal 18 September 2012 pukul 4.52 WIB.

27 Purqon Nur Ramdhan, Skripsi Studi Analisis Metode Hisab Arah Kiblat KH. Ahmad Ghozali dalam Kitab Irsyâd al-Murîd, Semarang: IAIN Walisongo, 2012, hlm. 54.

${ }^{28}$ Ibid. 
Kitab-kitab lain karya Ahmad Ghozali antara lain ${ }^{29}$; Azhar al-Bustan (Fiqh), al-Nujum al-Nayyirah (Hadis), Dlaw'u al-Badr (Jawaban Masalah Fiqh), al-Zahrat al-Wardiyah (Fara'id), Bughyat al-Wildan (Tajwid), al- Qawl al-Mukhtashor (Mustolah Hadis), Tuhfat al-Rawy (Tarajim), Tuhfat al-Arib (Tarajim), al-Taqyidat al-Jaliyah (Falak), Faidl al-karîm (Falak), Bughyat al-Rafìq (Falak), Anfa' alWashilah (Falak), Tsamarat al-Fikar (Falak), Irsyâd al-Murîd (Falak), al-Futuhat alRabbaniyyah (Mada'ih Nabawiyah), al- Fawakih al-Syahiyyah (Khutbah Minbariyah), Bughyat al-Ahbab (Fî al-Awrad Wa al-Ahzab), Majma' al-Fadla'il (Fî Ad'iyyah Wan Nawafil), Irsyâd al-Ibad (Fî al-Awrad) dan masih banyak lagi yang belum dicetak. ${ }^{30}$

Beberapa kitab tersebut memiliki konsen pembahasan yang berbeda serta menggunakan metode hisab yang berbeda pula, seperti kitab Tsamarat al-Fikar. Kitab tersebut membahas tentang waktu salat, hilal, dan gerhana dengan metode hisab hakiki tahkiki.

\section{Ketentuan untuk Hisab Awal Waktu Salat dalam Kitab Irsyâd al-Murîd}

Sebelum mengetahui langkah-langkah hisab awal waktu salat dalam kitab ini, ada beberapa hal yang harus diketahui yaitu: Pertama, mengenai kedudukan Matahari pada awal waktu-waktu salat. Awal waktu Zuhur adalah ketika zawal al-syams, artinya ketika Matahari telah melewati kulminasi atau istiwa', sedangkan istiwa sendiri berarti ketika Matahari tepat diatas sehingga apabila didirikan sebuah tongkat, tongkat tersebut tidak akan memiliki bayangan, dapat dirumuskan bahwa awal waktu Zuhur dapat diketahui dengan adanya sedikit bayangan tongkat yang didirikan, namun adakalanya ketika istiwa' tongkat yang didirikan tersebut memiliki bayangan kearah utara atau selatan, ini dikarenakan tidak selamanya Matahari tepat diatas, tergantung deklinasi Matahari. ${ }^{31}$

Adanya perbedaan awal waktu Zuhur diatas, maka berpengaruh pula dengan awal waktu Asar, karena akhir waktu Zuhur itu kadang ketika bayangan tongkat sama dengan panjang tongkat, dan kadang berakhir ketika panjang bayangan sama dengan panjang tongkat ditambah bayangan saat kulminasi maka itulah awal waktu salat Asar.

Untuk kedudukan Matahari atau tinggi Matahari pada saat terbenam dan terbit, Ahmad Ghozali dalam kitab ini memperhitungkan beberapa koreksi yaitu, refraksi, semi diameter, dip dan horizontal parallax.

Untuk kedudukan Matahari pada saat Maghrib, ulama berbeda pendapat yang mengatakan ho Isya berkisar 15o-18o, sedangkan Ahmad Ghozali dalam metode hisab awal waktu salat Isya menggunakan ho $-180 .{ }^{32}$

Kedudukan Matahari pada waktu Subuh Ahmad Ghozali menggunakan ketinggian -20o, serta 4.5o untuk ketinggian Matahari pada waktu Duha. ${ }^{33}$

Kedua, data lintang dan bujur suatu tempat serta selisih waktu suatu tempat dengan GMT (Greenwich Mean Time) dapat dilihat pada tabel dalam kitab Irsyâd alMurîd halaman 209-231. Misal akan menghitung awal waktu salat kota Semarang, maka lihat tabel pada halaman 226 kolom nomor 535, lintang sebesar 7o 00' bujur 110o 24' dan TZ 7.

\footnotetext{
${ }^{29}$ Ibid.

${ }^{30}$ Ibid.

31 Ahmad Ghazali Muhamad Fathullah, Irsyâd al-Murîd., Jember: Yayasan al-Nuriyyah, 1997, hlm. 34.

${ }^{32}$ Ibid.

${ }^{33}$ Ibid.
} 
Ketiga, data Matahari (deklinasi dan equation of time) dihitung sendiri, yang dalam kitab Irsyâd al-Murîd proses menghitung data Matahari dapat dilihat pada halaman 125-133. Misal pada tanggal 17 September 2012 pada pukul 12 setelah dihitung diketahui deklinasinya sebesar 2o 06' 13" dan equation of timenya sebesar 0 o 5 ' 36 .

Keempat, Ahmad Ghozali membagi waktu salat menjadi tiga yaitu, WIS (waktu istiwa), LMT (Local Mean Time) dan WIB (Waktu Indonesia bagian Barat). WIS adalah waktu yang didasarkan paada peredaran Matahari sebenarnya, yaitu Matahari berkulminasi pada pukul 12.00. LMT adalah waktu yang seolahsatu hari 24 jam, sehingga LMT dirumuskan: 12- perata waktu atau equation of time. WIB adalah waktu pertengahan yang didasarkan pada garis bujur tertentu, dalam contoh kitab ini bujur timur, WIB dirumuskan: WIS - equation of time + (BDx - BTx $).^{34}$

Terakhir, Ahmad Ghozali menggunakan 2 atau 3 untuk waktu ihtiyath, yaitu untuk kehati-hatian. ${ }^{35}$

\section{E. Analisis Metode Hisab Awal Waktu Salat KH. Ahmad Ghozali dalam kitab Irsyâd al-Murîd}

1. Teori yang digunakan KH. Ahmad Ghozali

Perhitungan posisi Bulan dan Matahari dalam kitab Irsyâd al-Murîd melakukan koreksi-koreksi hingga beberapa kali berdasarkan gerak Bulan dan Matahari yang tidak rata ${ }^{36}$.

Dalam perhitungan kitab ini, banyak istilah matematika yang menggunakan bahasa arab dengan istilah yang bermacam-macam, antara lain:

- $\quad$ Bujur Tempat

- $\quad=$ Lintang Tempat

- جيب = sinus ${ }^{37}$, perbandingan antara tinggi sebuah segitiga siku-siku denganpanjang sisi miringnya.

- $=$ cos, perbandingan proyeksi sisi miring dengan sisi itu sendiri dalam sebuah segitiga siku-siku ${ }^{38}$.

- $\quad=$ tangen, perbandingan jaib dengan jaib at-tamam (sinus dibagi cosinus). Kebalikannya, cotangen ( Dhil at-tamam). Besar dhil, jaib, maupun jaib altamam menentukan besar sudut. Dalam ilmu falak, hal itu sangat penting untuk menentukan benda langit, bahkan perhitungan-perhitungan lanjutan misalnya perkiraan jarak benda langit ${ }^{39}$. Ini menunjukkan bahwa dalam kitab ini menggunakan konsep dasar trigonometri.

Begitu pula dalam metode hisab sudut waktu awal salat yang digunakan oleh KH. Ahmad Ghazali adalah rumus-rumus yang memakai konsep segitiga bola (Spherical trigonometri). Karena perhitungan tersebut berpangkal pada teori yang dikemukakan oleh Copernicus (1473-1543) yakni teori Heliosentris. ${ }^{40}$ bahkan telah

${ }^{34}$ Ahmad Ghozali, loc.cit, hlm. 49.

${ }^{35}$ Ibid.

${ }^{36}$ Kitri Sulastri, Loc. Cit., hal. 58.

${ }^{37}$ Susiknan Azhari, Op. Cit., Hlm. 109.

${ }^{38}$ Ibid, Hlm. 200.

${ }^{39} \mathrm{Ibid}, \mathrm{Hlm} .56$.

${ }^{40}$ Teori heliosentris merupakan teori yang menempatkan Matahari sebagai pusat tatasurya. Lihat dalam Susiknan Azhari, Ilmu Falak "Perjumpaan Khazanah Islam dan Sains Modern", (Yogyakarta: Suara Muhammadiyah, 2007), hlm.15-16. 
menyerap Hukum Keppler ${ }^{41}$, yang menganggap bahwa bentuk lintasan orbit bumi adalah elips. Konsep Spherical trigonometri dapat kita lihat dalam mencari sudut waktu pada hisab awal waktu salat.

Dalam koreksi tinggi Matahari pada saat terbit dan terbenam, metode hisab dalam kitab ini juga memperhitungkan horizontal parallax $(h p)^{42}$, dimana dalam metode hisab awal waktu salat kontemporer lainnya kadang tidak memperhitungkannya.

2. Data yang digunakan dalam metode hisab awal waktu salat

Pengambilan data deklinasi matahari dan equation of time (perata waktu) dalam Metode kontemporer (ephemeris) mengambil data deklinasi matahari dan equation of time berdasarkan tabel ephemeris yang sudah tersedia. Tetapi dalam kitab Irsyâd al-Murîd harus melakukan beberapa tahapan dalam menghitung deklinasi matahari, karena dalam kitab tersebut tidak tersedia tabel deklinasi matahari dan equation of time. Di sinilah adanya ke-khasan dalam hisab data matahari untuk menghitung awal waktu salat pada kitab Irsyâd al-Murîd metode ini senada dengan mencari data deklnasi dan equation of time dalam Astronomical Algorithms-Jean Meus, hal ini tentu sangat wajar karena rujukan kitab ini adalah Astronomical Algorithms.

Sebenarnya untuk menghitung data matahari dan bulan secara astronomis dimulai dari suatu mabda' (epoch ${ }^{43}$ tertentu. Dalam hal ini dilakukan orang secara bervariasi, ada yang mabda'nya dimulai dari -46 SM sebagaimana ditempuh oleh sistem Julian, ada juga yang menghitung dari awal tahun masehi seperti yang ditempuh oleh sistem Basselian dan ada juga yang ditempuh dengan menentukan mabda' pada saat-saat tertentu sebagaimana ditempuh oleh sistem Newcomb ${ }^{44}$ dan beberapa perhitunganastronomis lainnya. ${ }^{45}$ Dalam Astronomical Alghorithms mengikuti ketentuan Julian calender $^{46}$ jadi harus mengkonversi tanggal yang akan digunakan ke mabda' yang dimulai pada 4712 SM pada jam 12 GMT, namun jika untuk keperluan untuk mencari data menggunakan Julian Ephemeris Day dengan mabda' tahun 2000. Begitu juga dalam kitab Irsyâd al-Murîd dalam menghitung data matahari terlebih dahulu megkonversi tanggal ke Julian Day (JD) lalu merubah ke mabda' 2000, dan dalam perhitungan dalam mencari data deklinasi dan equation of time sama dengan metode Jean Meus, hanya saja koreksinya lebih sedikit dalam Irsyâd al-Murîd bilangan polinomial hanya satu, sedangkan dalam Astronomical

\footnotetext{
${ }^{41}$ Penemu hukum ini yaitu John Kepler. Lihat dalam P. Simamora. Ilmu Falak (Kosmografi) “Teori, Perhitungan, Keterangan, dan Lukisan”, cet XXX, (Jakarta: C.V Pedjuang Bangsa, 1985), hlm. 46. Lihat juga M.S.L. Toruan, Pokok-Pokok Ilmu Falak (kosmografi), Cet IV, (Semarang: Banteng Timur, tt.), hlm. 104.

$42 \quad$ Rumus untuk memperhitungkan $h p=\tan ^{-1}$ (Jari-jari bumi : jarak matahari-bumi) $=$ tan ${ }^{l}(6371 ; 150.000 .000)=0.0024$. jadi dalam menghitung $h_{\text {terbitterbenam }}=-(s d+r e f+$ dip $)-h p$.

43 Permulaan atau tahun 0.

44 Ketentuan epoch menurut sistem Newcomb ditentukan pada jam 00 Januari 1960, hanya saja perlu diketahui karena data ini dibuat sebelum daerah waktu Indonesia dibagi menjadi 3 bagian waktu, jadi data ini masih menganut pembagian 6 waktu daerah. Dalam penggunaan hendaknya disesuaikan dengan bujur tempat yang akan dihitung, jika melakukan perhitungan pada posisi sebelah timur bujur tersebut dikurangi sebanyak gerak benda langit selama selisih waktu yang seimbang dengan selisih bujurnya, sedangkan untuk wilayah yang berada di sebelah baratnya daerah tersebut hendakya ditambah dengan gerak benda langit selama waktu yang seimbang dengan selisih bujurnya.

45 Encep Abdul Rojak, Modul Hisab Awal Bulan Hijriyah Kontemporer, Semarang:CSSMoraWS, 2011, hlm. 27.

46 Kalender yang dikenalkan sejak abad ke-46 SM oleh Julius Caesar dan digunakan sampai 1582 M (saat digunakan Kalender Gregorian).
} 
Alghorithms 4 sampai 5 (bilangan polinomial spt $\mathrm{T}, \mathrm{T}^{2}, \mathrm{~T}^{3}, \mathrm{~T}^{4}$ ). Lihat tabel perbedaan hisab mencari data Matahari antara Irsyâd al-Murîd dan Jean Meus

\begin{tabular}{|c|c|}
\hline Irsyaad al murid ${ }^{47}$ & Jean Meus ${ }^{48}$ \\
\hline JD & JD \\
\hline $\mathbf{T}$ & $\mathrm{T}$ \\
\hline $\begin{array}{l}S=\operatorname{Frac}((280.4665+36000.76983 \times T): \\
360) \times 360\end{array}$ & $\mathrm{~L}=280.4665^{\circ}+36000.7698 \mathrm{~T}$ \\
\hline $\begin{array}{l}M=\operatorname{Frac}((357.52910+35999.05030 \times T) \\
: 360) \times 360\end{array}$ & $\begin{array}{l}\mathrm{M}=357.52910^{\circ}+35999.05030^{\circ} \mathrm{T}- \\
0.0003032^{\circ} \mathrm{T}^{2}-0.00000048^{\circ} \mathrm{T}^{3}\end{array}$ \\
\hline $\begin{array}{l}\text { N= Frac }((125.04-(1934.136 \times T): 360) \\
\text { x } 360\end{array}$ & $\begin{array}{l}\quad=125.04452- \\
1934.136261 \mathrm{~T}+0.0020708 \mathrm{~T}^{2}+\mathrm{T}^{3} / 4 \\
50000\end{array}$ \\
\hline $\begin{array}{l}K^{\prime}=(17.264: 3600) \times \sin N+(0.206: \\
3600) \times \sin 2 N \\
K^{\prime \prime}=(-1.264: 3600) \times \sin 2 S\end{array}$ & $\begin{array}{l}\Psi=-17.20 " \sin \quad-0.57 ” \cos \\
2 L^{\prime}-0.09 " \cos 2\end{array}$ \\
\hline $\begin{array}{l}R^{\prime}=(9.23: 3600) x \cos N-(0.090: 3600) \\
x \cos 2 N \\
R^{\prime \prime}=(0.548: 3600) \times \cos 2 S\end{array}$ & $\begin{array}{l}\varepsilon=+9.20 " \cos +0.57 " \cos 2 \mathrm{~L} \\
+0.10 " \cos 2 \mathrm{~L} '-0.09 " \cos 2\end{array}$ \\
\hline $\begin{array}{l}Q=23.43929111+R 1+R 2- \\
(46.8150 / 3600) \times T\end{array}$ & $\varepsilon=\varepsilon_{0}+\varepsilon$ \\
\hline $\begin{array}{l}E=(6898.06: 3600) \times \sin m+(72.095: \\
3600) \times \sin 2 m+(0.966: 3600) \times \sin 3 m\end{array}$ & $\begin{array}{l}\mathrm{c}=+\left(1.914600^{\circ}-0.004817^{\circ} \mathrm{T}-\right. \\
\left.0.000014^{\circ} \mathrm{T}^{2}\right) \sin \mathrm{M}+\left(0.019993^{\circ}-\right. \\
\left.0.000101^{\circ} \mathrm{T}\right) \sin 2 \mathrm{M}+0.000290^{\circ} \sin \\
3 \mathrm{M}\end{array}$ \\
\hline$S^{\prime}=S+E+K 1+K 2-20.47^{\prime \prime}$ & $\begin{array}{l}\Theta=\mathrm{L}_{\mathrm{o}}+\mathrm{C}+\text { koreksi abrasi } \\
20.4898 \text { ") }+ \text { koreksi nutasi }(\psi)\end{array}$ \\
\hline D = Shift Sin $(\sin S 1 \times \sin Q 1)$ & $\operatorname{Sin} \delta=\sin \varepsilon \sin \Theta($ deklinasi $)$ \\
\hline $\begin{array}{l}S^{\prime}=S+E+K 1+K 2-20.47^{\prime \prime} \\
P T=S h i f t \tan (\tan S 1 \times \cos Q 1)\end{array}$ & $\mathrm{E}=\mathrm{L}_{\mathrm{o}}-0.0057183^{\circ}-\alpha+\psi \cdot \cos \varepsilon$ \\
\hline
\end{tabular}

Begitu juga untuk data koordinat kota-kota yang tercantum dalam kitab Irsyâd al-Murîd ini sama dengan tabel data dari buku Almanak Jamiliyah yang disusun oleh Sa'adoedin Djambek, seperti data Semarang dengan lintang $-7^{\circ} 00^{\prime} 00^{\prime \prime}$ LS dan bujur 1100 24' $00^{\prime \prime}$ $\mathrm{BT}^{49}$. begitu juga dalam Kitab Irsyâd al-Murîd data Semarang dengan lintang $-7^{\text {00000" }}$ LS dan bujur 1100 2400" BT. ${ }^{50}$

\section{Proses Hisab Awal Waktu Salat}

Proses hisab awal waktu salat Irsyâd al-Murîd tidak berbeda jauh dengan metode hisab kontemporer lainnya, khususnya Ephemeris. Untuk menghitung awal waktu salat, dibutuhkan data-data untuk proses hisab awal waktu salat, selanjutnya

\footnotetext{
47 Ahmad Ghozali Muhammad Fathullah, Op.Cit., hlm. 125-133.

48 Jean Meus, Astronomical Alghorithms, Virginia: Willmann-Bell, 1991, hlm. 59-153.

49 Ahmad Musonnif, Ilmu Falak (Metode Hisab Awal Waktu Salat, Arah Kiblat, Hisab Urfi dan Hisab Hakiki Awal Bulan), Yogyakarta: Teras, 2011, hlm. 85.

${ }^{50}$ Ahmad Ghazali Muhamad Fathullah, Op.Cit., Hlm. 226.
} 
mengetahui tinggi atau kedudukan Matahari pada awal waktu-waktu salat, kemudian menghitung sudut matahari pada tiap-tiap awal waktu salat, dan merubah sudut waktu menjadi jam serta ditambahkan ihtiyath sebagai pengaman perhitungan.

Walaupun proses hisab antara Irsyâd al-Murîd dan Ephemeris sama, namun ada beberapa hal yang berbeda, yang pertama adalah data yang digunakan, dalam Irsyâd al-Murîd data matahari (khususnya deklinasi dan equation of time) dihitung sendiri dengan metode yang mirip metode Jean Meus sedangkan dalam Ephemeris data (Deklinasi dan equation of time) diambil dari data Ephemeris, data matahari yang diambil adalah pada jam 5 GMT, karena sama dengan waktu hakiki (jam 12) untuk Indonesia (khususnya WIB) yang selisihnya 7 jam.

Kedua, tinggi matahari pada awal-awal waktu salat ada yang sama dan ada yang berbeda, untuk waktu Isya dan Subuh, tinggi matahari sama, sedangkan untuk $\mathrm{h}^{\mathrm{o}}$ maghrib, terbit, duha berbeda.

Ketiga, Koreksi untuk tinggi matahari dalam Irsyâd al-Murîd lebih banyak, memperhatikan refraksi, dip, semidiameter, da horizontal parallaks.

Terakhir, ihtiyath yang digunakan berbeda, dalam Irsyâd al-Murîd ihtiyath sebesar 2-3 menit, sedangkan dalam Ephemeris ihtiyath sebesar 1 menit lebih sesuai hasil untuk membulatkan hasil perhitungan, untuk lebih jelas dapat dilihat dalam proses hisab awal waktu salat dibawah ini:

a. Hisab Awal Waktu Salat dalam Kitab Irsyâd al-Murîd

Data yang dibutuhkan:

$$
\begin{aligned}
& \text { Tempat }=\text { Semarang } \quad \mathrm{TT}=100 \quad \mathrm{Sd}=0^{\circ} 16^{\prime} \\
& \mathrm{Tgl}=17 \mathrm{Sep} 2012 \quad \text { Ref }=0^{\circ} 34^{\prime} \\
& =-7^{\circ} 00^{\prime} \\
& \lambda=110^{\circ} 24^{\prime} \\
& \delta \quad=2^{\circ} 06^{\circ} 13^{\prime \prime} \\
& \text { e } \quad=0^{\circ} 5^{\circ} 36^{\prime \prime} \\
& \mathrm{Ku}=0^{\circ} 1,76^{\prime} \sqrt{ } 100 \\
& =0^{\circ} 17 ' 36^{\prime \prime} \\
& \mathrm{H}_{\text {asar }} \quad=\tan [-\delta]+1 \\
& \mathrm{H}_{\text {maghrib }} \quad=-(\operatorname{Ref}+\mathrm{sd}+\operatorname{dip})-\mathrm{hp} \\
& \mathrm{H}_{\text {isyak }} \quad=-18 \\
& \mathrm{H}_{\text {subuh }} \quad=-20 \\
& \mathrm{H}_{\text {imsak }} \quad=-22 \\
& \mathrm{H}_{\text {terbit }} \quad=-(\operatorname{Ref}+\mathrm{sd}+\mathrm{dip})-\mathrm{hp} \\
& \mathrm{H}_{\text {duha }} \quad=04^{\circ} 30^{\prime}
\end{aligned}
$$

Proses Perhitungan:

- Zuhur

$$
\begin{aligned}
\text { Zuhur } & =\mathrm{Pk} 12^{\circ} 00^{\prime} \text { WIS } \\
& =12^{\circ}-0^{\circ} 5{ }^{\circ} 36^{\prime \prime}=11^{\circ} 54^{`} 24^{\prime \prime} \mathrm{LMT}
\end{aligned}
$$$$
=12^{\circ}-0^{\circ} 5{ }^{`} 36^{\prime \prime}+\left((7 \times 15)-110^{\circ} 24^{\prime}\right)=11^{\circ} 32^{`} 48^{\prime \prime} \mathrm{WIB}
$$

- Asar

$$
\begin{aligned}
& \mathrm{B}=-7^{\circ} 00^{\prime}-2^{\circ} 06^{`} 13^{\prime \prime}=9^{\circ} 06^{\circ} 13^{\prime \prime} \text { (absolut) } \\
& \mathrm{H}=\tan ^{-1}\left(1:\left(\tan 9^{\circ} 06^{\circ} 13^{\prime \prime}+1\right)\right)=40^{\circ} 45^{\prime} 27.99^{\prime} \text { “ } \\
& \mathrm{F} \quad=-\tan -7^{\circ} 00^{\prime} \times \tan 2^{\circ} 06^{\prime} 13^{\prime \prime}=0^{\circ} 00^{\prime} 16.24^{\prime \prime} \\
& \mathrm{G} \quad=\cos -7^{\circ} 00^{\prime} \times \cos 2^{\circ} 06^{\circ} 13^{\prime \prime}=0^{\circ} 59^{\prime} 30.76^{\prime \prime} \\
& \text { Asar } \quad=\cos ^{-1}\left(0^{\circ} 00^{\prime} 16.24^{\prime \prime}+\sin 40^{\circ} 45^{\prime} 27.99^{\prime \prime}: 0^{\circ} 59^{\prime} 30.76^{\prime \prime}\right): 15 \\
& =3^{\circ} 13^{\prime} 58.17^{\prime \prime} \\
& =12^{\circ}+3^{\circ} 13^{\prime} 58.17^{\prime \prime} \text { WIS } \\
& =11^{\mathrm{o}} 54^{\circ} 24^{\prime \prime}+3^{\circ} 13^{\prime} 58.17^{\prime \prime}=15^{\circ} 8^{\prime} 22.17^{\prime \prime} \mathrm{LMT}
\end{aligned}
$$




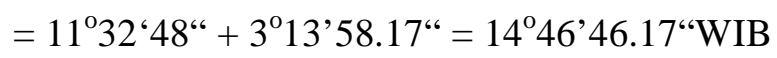

- Maghrib

$$
\begin{aligned}
& \mathrm{H}_{\text {maghrib }}=-\left(0^{\circ} 16^{\prime}+0^{\circ} 34+0^{\circ} 17^{\prime} 36^{\prime \prime}\right)-0^{\circ} 8^{\prime} 48^{\prime \prime}=-1^{\circ} 16^{\prime} 24^{\prime \prime} \\
& \text { Maghrib }=\cos ^{-1}\left(0^{\circ} 00^{\prime} 16.24^{\prime \prime}+-^{\circ} 16^{\circ} 24^{\prime \prime}: 0^{\circ} 599^{\prime} 30.76^{\prime \prime}\right): 15=6^{\circ} 44^{\prime} 6.06^{\prime \prime} \\
& =12^{\circ}+6^{\circ} 4^{\prime} 6.06^{\prime \prime}=18^{\circ} 4^{\prime} 6.06^{\prime \prime} \mathrm{WIS} \\
& =11^{\circ} 54^{\prime} 24^{\prime \prime}{ }^{\circ}+6^{\circ} 4^{\prime} 6.06^{\prime \prime}=17^{\circ} 58^{\prime} 30.06^{\prime \prime} \mathrm{LMT} \\
& =11^{\circ} 32^{\circ} 48^{\prime \prime}+6^{\circ} 4^{\prime} 6.06^{\prime \prime}=17^{\circ} 36^{\prime} 54.06^{\prime \prime} \mathrm{WIB}
\end{aligned}
$$

- Isya

Isya $\quad=\cos ^{-1}\left(0^{\circ} 00^{\prime} 16.24^{\prime “}+-18^{\circ}: 0^{\circ} 59^{\prime} 30.76^{\prime \prime}\right): 15=7^{\circ} 11^{\prime} 31.37^{\prime}$ “

$$
\begin{aligned}
& =12^{\circ}+7^{\circ} 11^{\prime} 31.37^{\prime \prime}=19^{\circ} 11^{\prime} 31.37^{\prime \prime} \mathrm{WIS} \\
& =11^{\circ} 54^{\circ} 24^{\prime \prime}+7^{\circ} 11^{\prime} 31.37^{\prime \prime}=19^{\circ} 5 \text { '55.37“ LMT } \\
& =11^{\circ} 32^{\circ} 48^{\prime \prime}+7^{\circ} 11^{\prime} 31.37^{\prime \prime}=18^{\circ} 44^{\prime} 19.37^{\prime \prime} \mathrm{WIB}
\end{aligned}
$$

- Subuh

Subuh

$$
\begin{aligned}
& =\cos ^{-1}\left(0^{\circ} 00^{\prime} 16.24^{\prime \prime}+-20^{\circ}: 0^{\circ} 59^{\prime} 30.76^{\prime \prime}\right): 15=7^{\circ} 19^{\prime} 34.98^{\prime \prime} \\
& =12^{\circ}-7^{\circ} 19^{\prime} 34.98^{\prime \prime}=4^{\circ} 40^{\prime} 25.02^{\prime \prime} \mathrm{WIS} \\
& =11^{\circ} 54^{\prime} 24^{\prime \prime}-7^{\circ} 19^{\prime} 34.98^{\prime \prime}=4^{\circ} 34^{\prime} 49.02^{\prime \prime L M T ~} \\
& =11^{\circ} 322^{\circ} 48^{\prime \prime}-7^{\circ} 199^{\prime} 34.98^{\prime \prime}=4^{0} 13 \text { '13.02“WIB } \\
& =4^{\mathrm{o}} 34^{\prime} 49.02^{\prime \prime}-0^{\mathrm{o}} 10^{\prime}=4^{\mathrm{o}} 24^{\prime} 49.02^{\prime \prime} \text { LMT } \\
& =4^{\circ} 13^{\prime} 13.02^{\prime \prime}-0^{\circ} 10^{\circ}=4^{\circ} 3 \text { ' } 13.02^{\prime \prime} \text { WIB }
\end{aligned}
$$

\begin{tabular}{|c|c|c|c|}
\hline Zuhur & Asar & Maghrib & Isya \\
\hline $11^{0} 34^{6} 48^{6}$ & $14^{\circ} 48^{\prime} 46.17^{66}$ & $1^{0} 388^{\prime} 54.06^{66}$ & $18^{\circ} 46^{\prime} 19.37^{66}$ \\
\hline Subuh & Imsak & Terbit & Duha \\
\hline $4^{\circ} 15^{\prime} 13.02^{66}$ & $4^{0} 5{ }^{\prime} 13.02^{66}$ & $5^{\circ} 30^{\prime} 41.94^{66}$ & $6^{0} 53$ '59.1'6 \\
\hline
\end{tabular}

- Imsak $=4^{\circ} 40^{\prime} 25.02^{\prime \prime}-0^{\circ} 10^{\circ}=4^{\circ} 30^{\prime} 25.02^{\prime \prime} \mathrm{WIS}$

- Terbit

terbit $\quad=\cos ^{-1}\left(0^{\circ} 00^{\prime} 16.24^{\prime \prime}+-1^{\circ} 16^{\prime} 24^{\prime \prime}: 0^{\circ} 59^{\prime} 30.76^{\prime \prime}\right): 15$

$=6^{\circ} 4^{\prime} 6.06^{\prime \prime}$

terbit $\quad=12^{\circ}-6^{\circ} 4^{\prime} 6.06^{\prime \prime}=5^{\circ} 55^{\prime} 53.94^{\prime \prime W I S ~}$

$=11^{\circ} 54^{\prime} 24^{\prime \prime}-6^{\circ} 4^{\prime} 6.06^{\prime \prime}=5^{\circ} 50$ ' 17.94 "LMT

$=11^{\circ} 32^{\circ} 48^{\prime \prime}-6^{\circ} 4^{\prime} 6.06^{\prime \prime}=5^{\circ} 28^{\prime} 41.94^{\prime \prime} \mathrm{WIB}$

- Duha

Duha $\quad=\cos ^{-1}\left(0^{\circ} 00^{\prime} 16.24^{\prime \prime}+\sin 4^{\circ} 30^{\circ}: 0^{\circ} 59^{\prime} 30.76^{\prime \prime}\right): 15$

$=5^{\circ} 40^{\prime} 48.9^{\prime \prime}$

Duha $\quad=12^{\circ}-5^{\circ} 40^{\prime} 48.9^{\prime \prime}=6^{\circ} 19^{\prime} 11.1^{\prime \prime} \mathrm{WIS}$

$=11^{\circ} 54^{\prime} 24^{\prime \prime}-5^{\circ} 40^{\prime} 48.9^{\prime \prime}=6^{\circ} 13^{\prime} 35.1^{\prime \prime} \mathrm{LMT}$

$=11^{\circ} 32^{\circ} 48^{\prime \prime}-5^{\circ} 40^{\prime} 48.9^{\prime \prime}=6^{\circ} 51^{\prime} 59.1^{\prime \prime} \mathrm{WIB}$

Tambahkan ihtiyat 2 atau 3 menit untuk kehati-hatian.

b. Hisab Awal waktu Salat sistem Ephemeris ${ }^{51}$

Data yang dibutuhkan:

51 Kemenag RI, Ephemeris Hisab Rukyat 2011, Jakarta: Kemenag RI, 2011, hlm. 411-414. 


$$
\begin{aligned}
& \text { Tempat }=\text { Semarang } \quad \mathrm{TT}=100 \quad \mathrm{Sd}=0^{\circ} 16^{\prime} \\
& \mathrm{Tgl}=17 \mathrm{Sep} 2012 \quad \text { Ref }=0^{\circ} 34^{\prime} \\
& =-7^{\circ} 00^{\prime} \\
& \lambda \quad=110^{\circ} 24^{\prime} \\
& \delta \quad=2^{\circ} 06^{\circ} 01^{\prime \prime} \\
& \text { e } \quad=0^{\circ} 5{ }^{\circ} 32^{\prime \prime} \\
& \mathrm{Ku}=0^{\circ} 1,76^{\prime} \sqrt{ } 100 \\
& =0^{\circ} 17^{\prime} 36^{\prime \prime} \\
& \text { bd } \quad=105^{\circ} \\
& =\tan \left[-7^{\circ} 00^{\prime}-2^{\circ} 06^{`} 01^{\prime \prime}\right]+1 \\
& =\tan 9^{\circ} 06^{\prime} 01^{\prime \prime}+1 \\
& =\operatorname{shift} \tan \left(1:\left(\tan 9^{\circ} 06^{\prime} 01^{\prime \prime}+1\right)\right)=40^{\circ} 45^{\prime} 33.24^{\prime \prime}
\end{aligned}
$$

Proses Perhitungan:

- Zuhur

Mer. Pass $=11^{\circ} 54^{\prime} 28^{\prime \prime}$ (LMT)

Interpolasi $=00^{\circ} 21^{\prime} 36^{\prime \prime}$

$$
=11^{\circ} 32^{\prime} 52^{\prime \prime}
$$

Ihtiyat $=\underline{00^{\circ} 01^{\prime} 06^{\prime \prime}+}+$

$$
=11^{\mathrm{j}} 34^{\mathrm{m}} 00^{\mathrm{d}}(\text { WIB })
$$

$$
\begin{aligned}
& =-\tan -7^{\circ} 00^{\prime} x \tan 2^{\circ} 06^{\circ} 01^{\prime \prime}+\sin 40^{\circ} 45^{\prime} 33.24^{\prime \prime}: \cos -7^{\circ} 00^{\prime} \text { : } \\
& \cos 2^{\circ} 06^{\circ} 01^{\prime \prime} \\
& \text { t } \quad=48^{\circ} 29^{\prime} 29.73^{\prime \prime} \\
& \text { MP }=11^{\mathrm{j}} 54^{\mathrm{m}} 28^{\mathrm{d}} \\
& \mathrm{t}: 15=\underline{03^{\mathrm{j}} 13^{\mathrm{m}} 57.98^{\mathrm{d}}+} \\
& =15^{\mathrm{j}} 08^{\mathrm{m}} 25.98^{\mathrm{d}}(\text { LMT }) \\
& \begin{aligned}
\text { Interpl } & =\underline{00^{\mathrm{j}} 21^{\mathrm{m}} 36^{\mathrm{d}}} \\
& =14^{\mathrm{j}} 46^{\mathrm{m}} 49.98^{\mathrm{d}}
\end{aligned} \\
& \text { Ihtiyat }=00^{\circ} 01^{\prime} 10.92 "+ \\
& \text { Asar }=14^{\mathrm{j}} 48^{\mathrm{m}} 00^{\mathrm{d}}(\mathrm{WIB})
\end{aligned}
$$

- Maghrib

$$
\begin{aligned}
\operatorname{Cos} \mathrm{t}_{\mathrm{magh}}= & -\tan \times \tan \delta+\sin \mathrm{h}_{\text {maghrib }}: \cos : \cos \delta \\
= & -\tan -7^{\circ} 00^{\prime} \times \tan 2^{\circ} 06^{\circ} 01^{\circ}+\sin -1^{\circ}: \cos -7^{\circ} 00^{\prime}: \\
& \cos 2^{\circ} 06^{\circ} 01^{\prime \prime}
\end{aligned}
$$




$$
\begin{aligned}
& \mathrm{t} \quad=90^{\circ} 45^{\prime} 0.58^{\prime \prime} \\
& \text { MP }=11^{\mathrm{j}} 54^{\mathrm{m}} 28^{\mathrm{d}} \\
& \mathrm{t}: 15=\underline{6^{\circ} 03^{\prime} 0.04^{\prime \prime}+} \\
& =17^{\mathrm{j}} 57^{\mathrm{m}} 28.04^{\mathrm{d}}(\mathrm{LMT}) \\
& \text { Interpl }=00^{\mathrm{j}} 21^{\mathrm{m}} 36^{\mathrm{d}} \\
& ={\overline{17^{\mathrm{j}} 35^{\mathrm{m}} 52.04^{\mathrm{d}}}}^{\mathrm{d}}
\end{aligned}
$$

Ihtiyat $=\underline{00^{\circ} 01^{\prime} 07.96 "}+$

$$
\text { Magh }=17^{\mathrm{j}} 37^{\mathrm{m}} 00^{\mathrm{d}}(\text { WIB })
$$

- Isya

Cos $\mathrm{t}_{\text {isya }}=-\tan \mathrm{x} \tan \delta+\sin \mathrm{h}_{\text {isya }}: \cos : \cos \delta$

$=-\tan -7^{\circ} 00^{\prime} \times \tan 2^{\circ} 06^{\circ} 01^{\prime \prime}+\sin -18^{\circ}: \cos -7^{\circ} 00^{\prime}:$ $\cos 2^{\circ} 06^{\circ} 01^{\prime \prime}$

$$
\begin{aligned}
\mathrm{t} & =107^{\mathrm{o}} 52^{\prime} 52.2^{،} \\
\mathrm{MP} & =11^{\mathrm{j}} 54^{\mathrm{m}} 28^{\mathrm{d}} \\
\mathrm{t}: 15 & =7^{\mathrm{o}} 11^{\prime} 31.48^{\circ}+ \\
& =19^{\mathrm{j}} 5^{\mathrm{m}} 59.48^{\mathrm{d}}(\text { LMT }) \\
\text { Interpl } & =00^{\mathrm{j}} 21^{\mathrm{m}} 36^{\mathrm{d}}- \\
& =18^{\mathrm{j}} 44^{\mathrm{m}} 23.48^{\mathrm{d}}
\end{aligned}
$$

Ihtiyat $=\underline{00^{\circ} 01^{\prime} 36.52^{\prime \prime}+}$

$$
\text { isya }=18^{\mathrm{j}} 46^{\mathrm{m}} 00^{\mathrm{d}}(\mathrm{WIB})
$$

- Subuh

$$
\begin{aligned}
& \operatorname{Cos} \mathrm{t}_{\text {subuh }}=-\tan \times \tan \delta+\sin \mathrm{h}_{\text {subuh }}: \cos : \cos \delta \\
& =-\tan -7^{\circ} 00^{\prime} \times \tan 2^{\circ} 06^{\circ} 01^{\prime \prime}+\sin -20^{\circ}: \cos -7^{\circ} 00^{\prime}: \\
& \cos 2^{\circ} 06^{\prime} 01^{\prime \prime} \\
& \mathrm{t}=107^{\circ} 52^{\prime} 52.2^{\prime *} \\
& \text { MP }=11^{\mathrm{j}} 54^{\mathrm{m}} 28^{\mathrm{d}} \\
& \mathrm{t}: 15=\underline{7^{\mathrm{o}} 11{ }^{\prime} 31.48^{\prime \prime}} \\
& =4^{\mathrm{j}} 42^{\mathrm{m}} 56.52^{\mathrm{d}}(\mathrm{LMT}) \\
& \begin{aligned}
\text { Interpl } & =0.00^{\mathrm{j}} 21^{\mathrm{m}} 36^{\mathrm{d}} \\
& =4^{\mathrm{j}} 21^{\mathrm{m}} 20.52^{\mathrm{d}}
\end{aligned} \\
& \text { Ihtiyat }=\underline{00^{\circ} 01 ' 39.48^{\prime \prime}}+ \\
& \text { Subuh }=4^{\mathrm{j}} 23^{\mathrm{m}} 00^{\mathrm{d}}(\text { WIB }) \\
& \text { Cos } \mathrm{t}_{\text {imsak }}=-\tan \times \tan \delta+\sin \mathrm{h}_{\text {imsak }}: \cos : \cos \delta \\
& =-\tan -7^{\circ} 00^{\prime} \times \tan 2^{\circ} 06^{\circ} 01^{\prime \prime}+\sin -22^{\circ}: \cos -7^{\circ} 00^{\prime} \text { : } \\
& \cos 2^{\circ} 06^{\prime} 01^{\prime \prime} \\
& \mathrm{t}=111^{\mathrm{o}} 54^{\prime} 40.6^{\prime \prime} \\
& \text { MP }=11^{\mathrm{j}} 54^{\mathrm{m}} 28^{\mathrm{d}} \\
& \mathrm{t}: 15=7^{\mathrm{o}} 27^{\prime} 38.71^{\prime \prime}-
\end{aligned}
$$




\begin{tabular}{|c|c|c|c|}
\hline \multicolumn{4}{|c|}{$\begin{aligned} & =4^{\mathrm{j}} 26^{\mathrm{m}} 49.29^{\mathrm{d}}(\mathrm{LMT}) \\
\text { Interpl } & =\frac{00^{\mathrm{j}} 21^{\mathrm{m}} 36^{\mathrm{d}}}{} \\
& =4^{\mathrm{j}} 05^{\mathrm{m}} 13.29^{\mathrm{d}}\end{aligned}$} \\
\hline \multicolumn{4}{|c|}{ Ihtiyat $=\underline{00^{\circ} 01^{\prime} 13.29^{\prime \prime}-}$} \\
\hline $\begin{array}{r}\text { Imsak } \\
\text { - } \quad \text { Terbit } \\
\end{array}$ & \multicolumn{3}{|l|}{$=4^{\mathrm{j}} 04^{\mathrm{m}} 00^{\mathrm{d}}(\mathrm{WIB})$} \\
\hline \multirow{2}{*}{$\begin{aligned} \text { Cos } t_{\text {terbit }} & = \\
& =\end{aligned}$} & \multicolumn{3}{|c|}{$=-\tan \quad x \tan \delta+\sin h_{\text {terbit }}: \cos \quad: \cos \delta$} \\
\hline & \multicolumn{3}{|c|}{$\begin{aligned}= & -\tan -7^{\circ} 00^{\prime} \times \tan 2^{\circ} 06^{\circ} 01^{\prime \prime}+\sin -1^{\circ}: \cos -7^{\circ} 00^{\prime}: \\
& \cos 2^{\circ} 06^{\circ} 01^{\prime \prime}\end{aligned}$} \\
\hline $\mathrm{t}$ & \multicolumn{3}{|l|}{$=90^{\circ} 45^{\prime} 0.58^{\prime \prime}$} \\
\hline MP & \multicolumn{3}{|l|}{$=11^{\mathrm{j}} 54^{\mathrm{m}} 28^{\mathrm{d}}$} \\
\hline $\mathrm{t}: 15$ & \multicolumn{3}{|l|}{$=\underline{6^{\circ} 03^{\prime} 0.04^{6 *}-}$} \\
\hline 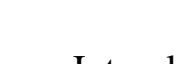 & \multicolumn{3}{|c|}{ 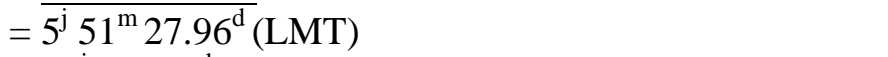 } \\
\hline Interpl & \multicolumn{3}{|c|}{$=00^{\mathrm{j}} 21^{\mathrm{m}} 36^{\mathrm{d}}-$} \\
\hline Ihtiyat & \multicolumn{3}{|l|}{$=\underline{00^{\circ} 01^{\prime} 51.96^{\prime \prime}}-$} \\
\hline $\begin{array}{l}\text { terbit } \\
\text { - Duha }\end{array}$ & \multicolumn{3}{|l|}{$=5^{\mathrm{j}} 28^{\mathrm{m}} 00^{\mathrm{d}}(\mathrm{WIB})$} \\
\hline \multirow[t]{2}{*}{ Cos $t_{\text {duha }}$} & \multirow{2}{*}{\multicolumn{3}{|c|}{$\begin{aligned}= & -\tan \times \tan \delta+\sin \mathrm{h}_{\text {duha }}: \cos : \cos \delta \\
= & -\tan -7^{\circ} 00^{\prime} \times \tan 2^{\circ} 06^{\circ} 01^{\prime \prime}+\sin -3^{\circ} 30^{\prime}: \cos -7^{\circ} 00^{\prime}: \\
& \cos 2^{\circ} 06^{`} 01^{\prime “}\end{aligned}$}} \\
\hline & & & \\
\hline $\mathrm{t}$ & \multicolumn{3}{|l|}{$=86^{\circ} 12^{\prime} 46.03^{\prime \prime}$} \\
\hline MP & \multicolumn{3}{|l|}{$=11^{\mathrm{j}} 54^{\mathrm{m}} 28^{\mathrm{d}}$} \\
\hline $\mathrm{t}: 15$ & \\
\hline \multicolumn{4}{|c|}{$\begin{aligned} \text { Interpl } & =00^{\mathrm{j}} 21^{\mathrm{m}} 36^{\mathrm{d}} \\
& =5^{\mathrm{j}} 48^{\mathrm{m}} 0.93^{\mathrm{d}}\end{aligned}$} \\
\hline \multirow{2}{*}{\multicolumn{4}{|c|}{$\begin{array}{l}\text { Ihtiyat }=00^{\circ} 01^{\prime} 59.07^{\prime \prime}+ \\
\text { duha }=5^{\mathrm{j} 50^{\mathrm{m}} 00^{\mathrm{d}}(\mathrm{WIB})}\end{array}$}} \\
\hline & & & \\
\hline zuhur & Asar & Maghrib & Isya \\
\hline $134^{\mathrm{m}} 00^{\mathrm{d}}$ & $14^{\mathrm{j}} 48^{\mathrm{m}} 00^{\mathrm{d}}$ & $17^{\mathrm{j}} 37^{\mathrm{m}} 00^{\mathrm{d}}$ & $18^{\mathrm{j}} 38^{\mathrm{m}} 00^{\mathrm{d}}$ \\
\hline ubuh & Imsak & Terbit & Duha \\
\hline $23^{m} 00^{d}$ & $4^{j} 04^{m} 00^{d}$ & $5^{\mathrm{j}} 28^{\mathrm{m}} 00^{\mathrm{d}}$ & $5^{j} 50^{m} 00^{d}$ \\
\hline
\end{tabular}

\section{F. Analisis keakurasian Metode Hisab Awal Waktu Salat KH. Ahmad Ghozali dalam kitab Irsyâd al-Murîd}

Tingkat keakurasian dari berbagai metode memang masih belum bisa dibuktikan. Dalam menganalisis tingkat akurasi Hisab Awal Waktu Salat Irsyâd alMurîd maka perlu tolak ukur, dan tolak ukur dalam menentukan awal waktu salat adalah metode kontemporer (ephemeris) yang dianggap modern dan dianggap memiliki keakurasian tinggi, karena perhitungannya menggunakan data-data yang 
dibantu oleh alat canggih seperti kalkulator, GPS, kompas, satelit, dan lain-lain, yang memiliki tingkat kesalahan kecil selain itu sistem Ephemeris juga digunakan oleh pemerintah Indonesia (Badan Hisab Rukyah). Oleh karena itu, penulis akan membandingkan hasil perhitungan awal waktu salat dalam kitab tersebut dengan metode kontemporer (ephemeris).

1. Keakurasian data matahari yang digunakan Irsyâd al-Murîd dibandingkan dengan data Ephemeris, lihat tabel data matahari dibawah ini; 
Tabel Data Matahari pada tanggal 17 September 2012 jam 12 WIB

\begin{tabular}{|c|c|c|}
\hline Data Matahari & Irsyâd al-Murîd ${ }^{52}$ & Ephemeris $^{53}$ \\
\hline Deklinasi $(\delta)$ & $2^{\circ} 06^{\circ} 13^{\prime \prime}$ & $2^{\circ} 06^{\circ} 01^{\prime \prime}$ \\
\hline Equation of time (e) & $0^{\circ} 5^{\prime} 36^{\prime c}$ & $0^{\circ} 5^{\prime} 32^{،}$ \\
\hline
\end{tabular}

Dari tabel diatas dapat kita simpulkan bahwa data deklinasi dan equation of time dalam Irsyâd al-Murîd sudah akurat karena hampir sama dengan data yang disajikan dalam Ephemeris, hanya selisih di detik.

Jika dalam Jean Meus, keakurasian dibagi kedalam tiga tingkat, ada yang low accuracy, medium accuracy, dan high accuracy. Dalam perhitungan data matahari pada kitab Irsyâd alMurîd termasuk tingkat low accuracy, namun tetap dapat digunakan. Karena walaupun beda pengelompokan tingkat, namun selisih keakurasian hanya sedikit sekali.

1. Keakurasian hasil hisab awal waktu salat dalam kitab Irsyâd al-Murîd dibandingkan dengan hasil hisab awal waktu salat sistem Ephemeris, yang dianggap akurat oleh ahli falak, Indonesia khususnya, lihat tabel dibawah ini:

Jadwal Waktu Salat tanggal 17 September 2012 markaz Semarang

\begin{tabular}{|c|c|c|}
\hline Waktu Salat & Irsyâd al-Murîd $^{54}$ & Ephemeris $^{55}$ \\
\hline Dzuhur & $11^{\circ} 34^{6} 48^{66}$ & 11'34'00"' \\
\hline Asar & $14^{0} 48^{6} 46.17^{66}$ & $14^{\circ} 48^{\prime} 00^{\prime \prime}$ \\
\hline Maghrib & $17^{0} 388^{\prime} 54.06^{66}$ & 17³7'00”' \\
\hline Isya & $18^{\circ} 46^{\prime} 19.37^{66}$ & $18^{\circ} 46^{\prime} 00^{\prime \prime}$ \\
\hline Subuh & $4^{0} 15^{\prime} 13.02^{66}$ & $4^{0}$ 23' 00"' \\
\hline Imsak & $4^{0} 07^{\prime} 13.02^{66}$ & $4^{0} 04^{\prime} 00^{\prime \prime}$ \\
\hline Terbit & $5^{0} 30^{\prime} 41.94^{66}$ & $5^{\circ} 28$ '00" \\
\hline Duha & $5^{0} 53^{6} 59^{66}$ & $5^{\circ} 50^{\prime} 00^{\prime \prime}$ \\
\hline
\end{tabular}

Dari tabel hasil hisab awal waktu salat kota Semarang di atas, dapat kita simpulkan bahwa hasil hisab dalam Irsyâd al-Murîd tidak berbeda jauh dengan hasil hisab awal waktu salat sistem Ephemeris, hanya selisih kurang lebih 2sampai 3 menit. Jadi dapat dikatakan bahwa hasil hisab awal waktu salat dalam Irsyâd al-Murîd sudah akurat dan dapat digunakan oleh masyarakat untuk ibadah.

\section{G. Penutup}

52 Data diperoleh dari perhitungan, lihat lampiran 1.

53 Data diperoleh dari table Ephemeris pada jam 5 GMT (12 WIB), lihat lampiran 2.

54 Data diperoleh dari perhitungan di atas, lihat juga Ahmad Ghazali Muhamad Fathullah, Loc.Cit, Hlm. 49-56.

55 Data diperoleh dari perhitungan sistem Ephemeris, lihat perhitungan diatas. Lihat juga Slamet Hambali. Op. Cit. hlm. 141-150. 
Metode hisab awal waktu salat dalam kitab Irsyâd al-Murîd karangan KH. Ahmad Ghazali tergolong metode hisab kontemporer atau modern yang memiliki kesamaan dan perbedaan dengan metode kontemporer lainnya (ephemeris). Persamaannya adalah rumus yang digunakan dalam menghitung sudut waktu matahari pada awal waktu-waktu salat tidak berbeda dengan metode kontemporer (ephemeris) karena kitab tersebut berpijak pada literatur kontemporer juga yaitu Astronomical Algorithms/Jean Meeus, yang rumusnya merupakan bentuk turunan dari teori dasar segitiga bola dan perhitungannya pun menggunakan kalkulator. Sedangkan perbedaanya antara lain:

a) Penggunaan data matahari yang berbeda. Dalam kitab Irsyâd al-Murîd, data matahari seperti deklinasi dan equation of time, didapat secara manual melalui perhitungan yang panjang dengan metode yang hampir sama dengan Jean Meus. Sedangkan metode ephemeris hanya menggunakan data matahari tersebut berdasarkan data yang tersedia dalam buku ephemeris yang bisa dilihat dan dicetak dari software winhisab.

b) Koreksi tinggi matahari pada saat terbit dan terbenam dalam kitab Irsyâd al-Murîd, lebih teliti karena memperhitungkan refraksi, semidiameter, dip, dan horizontal parallax, sedangkan dalam ephemeris hanya menetapkan $-1^{\circ}$.

Kitab Irsyâd al-Murîd memiliki tingkat akurasi tinggi, karena rumus yang digunakan adalah berupa turunan dari segitiga bola dengan menggunakan input data yang tidak jauh berbeda dengan ephemeris, dari hasil perhitungan pun hasilnya tidak jauh berbeda hanya selisih sekitar 2-3 menit. Sehingga kiranya tidak berlebihan jika dikatakan bahwa sistem kitab tersebut dapat dinyatakan up to date dan relevan bila dijadikan sebagai salah satu pedoman dalam hisab awal waktu salat era sekarang ini. 


\section{Daftar Pustaka}

Al-Qohtani, Sa'id bin Ali bin Wahf, Ensiklopedi Salat menurut al-Qur'an dan Sunnah, JATCC: Pustaka Imam Al-Syafi'i, 2008.

Azhari, Susiknan, Ilmu Falak Perjumpaan Khazanah Islam dan Sains Modern, Yogyakarta: Suara Muhammadiyah, Cet.II, 2007.

Susiknan, Hisab \& Rukyah "Wacana Untuk Membangun Kebersamaan di Tengah Perbedaan”, Yogyakarta: Pustaka Pelajar, 2007.

Susiknan, Ensiklopedi Hisab Rukyah, Pustaka Pelajar: Yogyakarta, 2005, cet I.

Departemen Agama Republik Indonesia, al-Quran Dan Terjemahnya, Jakarta: Bumi Restu, 1974, hlm. 125.

Fathullah, Ahmad Ghazali Muhamad, Irsyâd al-Murîd., Jember: Yayasan al-Nuriyyah, 1997.

Hambali, Slamet, Ilmu Falak 1, Semarang: Program Pascasarjana IAIN Walisongo, 2012.

Husain, Taqiyuddin Abi Bakar Muhammad, Kifayah al-Akhyar Fi Halli Gayatul Ikhtisar, Juz. I, Surabaya: Dar al-Kitab al-Islam.

Idris, Imam Syafi'i Abu Abdullah Muhammad bin, Mukhtashar Kitab Al-Umm fiil Fiqhi, Mohammad Yasir Abd Muthalib, "Ringkasan Kitab Al Umm”,Jakarta: Pustaka Azzam, 2004.

Izzuddin, Ahmad, Ilmu Falak Praktis (Metode Hisab-Ru'yah dan Solusi Permasalahannya), Semarang: Komala Grafika, 2006.

Jamil, A, Ilmu Falak (Teori dan Praktek), Amzah: Jakarta, 2009.

Khazin, Muhyiddin, Kamus Ilmu Falak, Buana Pustaka: Yogyakarta, 2005.

Kemenag RI, Ephemeris Hisab Rukyat 2011, Jakarta: Kemenag RI, 2011.

Meus, Jean, Astronomical Alghorithms, Virginia: Willmann-Bell, 1991.

Musonnif, Ahmad, Ilmu Falak (Metode Hisab Awal Waktu Salat, Arah Kiblat, Hisab Urfi dan Hisab Hakiki Awal Bulan), Yogyakarta: Teras, 2011.

Ramdhan, Purqon Nur, Skripsi Studi Analisis Metode Hisab Arah Kiblat KH. Ahmad Ghozali dalam Kitab Irsyâd al-Murîd, Semarang: IAIN Walisongo, 2012..

Rojak, Encep Abdul, Modul Hisab Awal Bulan Hijriyah Kontemporer, Semarang:CSSMoraWS, 2011.

Simamora, P., Ilmu Falak (Kosmografi) “Teori, Perhitungan, Keterangan, dan Lukisan”, cet XXX (Jakarta: C.V Pedjuang Bangsa, 1985).

Sulastri, Kitri, "Studi Analisis Hisab Awal Bulan Kamariah dalam Kitab Irsyâd al-Murîd", Semarang: IAIN Walisongo, 2010. 